\title{
Risk factors associated with tilapia and pangasius diseases
}

\author{
M. A. R. Faruk, N. Rahman and Z. P. Patwary ${ }^{1}$ \\ Department of Aquaculture, Bangladesh Agricultural University, Mymensingh 2202, Bangladesh \\ ${ }^{1}$ Department of Aquaculture, Hajee Mohammad Danesh Science \& Technology University, Dinajpur-5200, Bangladesh
}

\begin{tabular}{|c|c|}
\hline ARTICLE INFO & Abstract \\
\hline $\begin{array}{l}\text { Article history: } \\
\text { Received: } 06 \text { August } 2017 \\
\text { Accepted: } 24 \text { October } 2017\end{array}$ & $\begin{array}{l}\text { Tilapia (Oreochromis niloticus) and pangasius (Pangasianodon hypophthalmus) are currently very } \\
\text { important and popular species for aquaculture in Bangladesh. They are cultured commercially in high } \\
\text { stocking densities which are accompanied by several risk factors leading to disease outbreaks. The present } \\
\text { study was carried out to investigate diseases of these two species under farming condition with special }\end{array}$ \\
\hline $\begin{array}{l}\text { Keywords: } \\
\text { Riskfactor,Tilapia, Pangasius, } \\
\text { Disease }\end{array}$ & $\begin{array}{l}\text { emphasis on risk factors analysis and their health management strategies. Data were collected through } \\
\text { questionnaire interview and focus group discussion with farmers. Altogether } 50 \text { farmers were interviewed } \\
\text { of which } 25 \text { were tilapia farmers and } 25 \text { were pangus farmers in Trishal upazila of Mymensingh district. } \\
\text { Possible risks were assessed using certain parameters like season of disease occurrence, presence of } \\
\text { predators in farms, contact with livestock maintenance of farm hygiene, sharing of farming tools, feeding }\end{array}$ \\
\hline $\begin{array}{l}\text { Correspondence: } \\
\text { M.A.R. Faruk } \\
\text { (hasin96@yahoo.com) }\end{array}$ & $\begin{array}{l}\text { of fish and pond management measures. It was found that presence of predatory birds, maintenance of } \\
\text { good farm hygiene, sharing of tools, increased stocking densities and improper pond management were } \\
\text { the major risks of disease outbreak. The most prevalent clinical signs of diseased fish included anal } \\
\text { protrusion and red spot on body surface in case of pangus while pop and red eye and gas problems were } \\
\text { common in both pangasius and tilapia. Generally, pangus were found more susceptible to disease than } \\
\text { tilapia. Predatory birds were a big problem in the study area. They act as a potential carrier of infectious } \\
\text { organisms among farms from farm to farm. }\end{array}$ \\
\hline
\end{tabular}

\section{Introduction}

Tilapia (Oreochromis niloticus) and pangasius (Pangasianodon hypophthalmus) are the two most important species for aquaculture of Bangladesh particularly for their fast growth, year round production and high productivity. They are commonly cultured all over the country. Currently, tilapia has emerged to become the second biggest aquatic species group after the carp group (FAO, 2015). Tilapia production in Bangladesh has increased from 2,140 mt in 1999 to about 423,000 mt in 2015 and currently, Bangladesh ranked 4th among top ten tilapia producers in the world (FAO, 2017). Tilapia has good resistance to poor water quality and diseases, tolerance of wide range of environmental condition, ability to convert efficiently the organic and domestic waste into high quality protein. Pangusius farming is also playing a significant role to meet the increasing demand for food fish. Though the estimates of annual production of pangasius vary but it is believed that it is within the range of 300,000-400,000 $\mathrm{mt}$ (Haque et al., 2013). Local market demand for pangus is very high because of low price and it appears as pro-poor fish.

Generally, both farmed and wild fishes have been found to be affected by various kinds of diseases every year. Common diseases of freshwater fishes of Bangladesh are various bacterial, fungal, viral, protozoan, metazoan, parasitic, nutritional and environmental diseases (Chowdhury, 1998; Faruk, 2004). Despite the prevalence, very little study has been conducted to describe outbreaks of this disease under field conditions, and identify and quantify important risk factors that influence the occurrence of diseases on fish farms. Because diseases of farmed fish typically have a multifactorial etiology (Hedrick, 1998; Thorburn, 1999), epidemiological information gained from studying risk factors for diseases of cultured fish is considered essential for the prevention and control of such outbreaks (Georgiadiset al., 2001).A risk factor is a variable associated with an increased risk of disease or infection. It could be any attribute, characteristics or exposure of an individual that increases the likelihood of developing a disease or injury (WHO, 2016). Disease predisposition in fish could be the end result of an interaction between host susceptibility, pathogen virulence and environmental factors (Kumer, 2006).

In recent times, however, with the rapid expansion of farming there has been reports of serious disease outbreaks and mortality of both tilapia and pangus (M. A. Hoaasin, personal communication, January 15, 2016).It is therefore, important to know the risk factors associated with disease outbreak for better health management and disease control. The objectives of the present study weretherefore to understand disease condition of farmed tilapia and pangus fish and to identify the risk factors associated with diseases. 


\section{Materials and Methods}

The present study was focused on commercial pangus and tilapia farm of Trishalupazila under Mymensingh district. Total 50 farmers (25 tilapia farmers and 25 pangus farmers) were in the target group. Primary data was collected through questionnaire survey and focus group discussion (FGD). Secondary data were obtained from government and non-government organizations. For questionnaire interview, a set of prepared preliminary questionnaire was focused mainly on general pangus and tilapia farming characteristics, culture practices, duration, water source, disease surveillance and risk factors, source and management aspect of fry and feed, disease control measures and hygiene standards. The preliminary questions then were tested at the field level and then final set questionnaire was developed. Six FGDs were conducted with farmers. The clinically observed fish photos were taken by camera to store the disease evidence from the study areas. The data were aggregated and sorted carefully before making tabular forms. The data were then tabulated in the computer and raw data were entered in the spread sheet of the Microsoft Office Excel program to analyze. Some of the collected data in the informative forms were converted into descriptive results.

\section{Results}

\section{Culture strategy}

Two types of culture system were practiced by the farmers in study area; polyculture and monoculture. Average $86.7 \%$ tilapia farmers practiced polycultue system while only $13.3 \%$ farmers relied on monoculture. Farmers were fond of pangus and tilapia mixed culture because it is more cost effective than others. Average $71.4 \%$ of pangus farmers practiced polyculture system and $28.6 \%$ engaged in monoculture system (Fig. 1). For polyculture system farmers used different species of carps with tilapia and pangus. They also used shing (Heteropneustes fossilis), magur (Clarias batrachus) and koi (Anabas testudineus). In the study area all farmers had deep tube-well for pumping underground water when required. In addition, some pangus farms used river water and water from nearby beels.

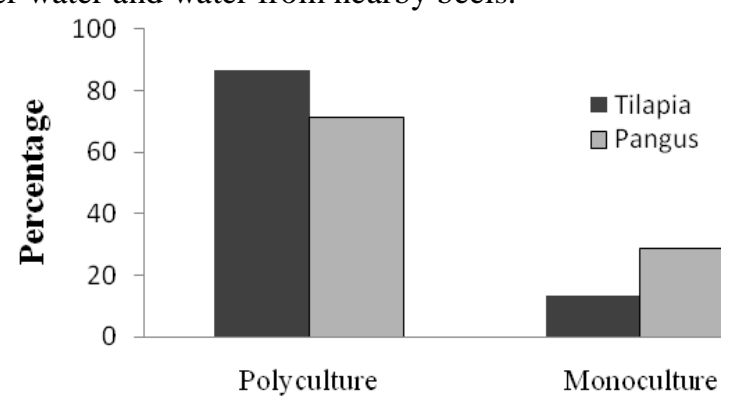

Culture System

Fig. 1. Culture system followed by farmers in the study area

\section{Source of fry and feed}

About $73.3 \%$ tilapia farmers collected their fry from other hatchery while $26.7 \%$ farmers had their own hatchery. In case of pangus most of the farmers $(85.7 \%)$ collected fry from other hatchery especially from Santaher, Naogaon in plastic drums and $20.5 \%$ farmers used their own hatchery breed fry. Overall $79.5 \%$ farmers collected fish from other hatchery (Table 1).

About $73.3 \%$ of the tilapia farmers used commercial feed and $26.7 \%$ of farmers had their own feed mill or machine. About $71.4 \%$ pangus farmers used home-made feed while $28.6 \%$ farmers used commercial feed (Table 1). Pangus farmers made their feed by mixing of rice bran, rice polish, soybean oilcake, dry fish, meat bone meal, salt and flour. Most of the farmers feed their fish two times in a day.

Table 1. Sources of fry (\%) and feed in the study area

\begin{tabular}{ccccc}
\hline Criteria & Source & $\begin{array}{c}\text { Tilapia } \\
(\mathbf{n = 2 5})\end{array}$ & $\begin{array}{c}\text { Pangus } \\
(\mathbf{n = 2 5})\end{array}$ & Mean \pm SD \\
\hline Sources of fry & Other hatchery & 73.3 & 85.7 & $79.50 \pm 8.77$ \\
& Own hatchery & 33.3 & 14.3 & $23.80 \pm 13.43$ \\
Sources of feed & Commercial feed & 73.3 & 28.6 & $50.95 \pm 31.61$ \\
& Homemade feed & 26.7 & 71.4 & $49.05 \pm 31.61$ \\
\hline
\end{tabular}

\section{Disease outbreak in farms}

When farmers were asked about disease problem in past, majority of farmers said they had problems in the recent past. All the pangus farmers and about $80 \%$ tilapia farmers faced disease problem of their fish in the past. During the study period it was observed that $85.7 \%$ pangus farmers had disease in their ponds while $13.3 \%$ tilapia farmers had disease in their farms (Fig. 2).

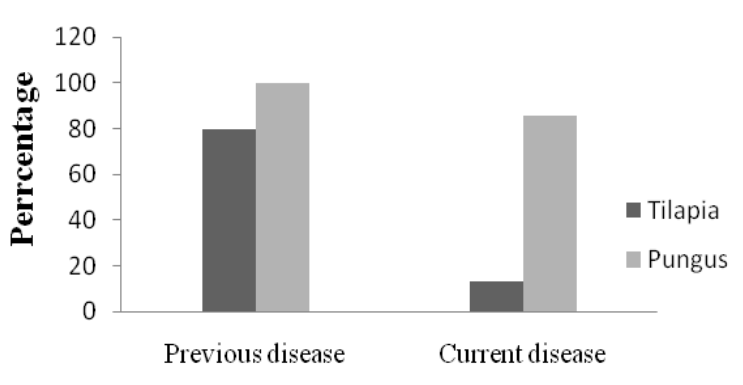

Disease history

Fig. 2.History of disease in the study area 


\section{Clinical signs of diseased fishes}

A number of clinical signs were reported according to their occurrence. The most commonly occurred clinical signs of pangus included anal protrusion (64.29\%), pop eye $(42.85 \%)$, red eye $(42.85 \%)$, reddening of body $(35.73 \%)$, tail rot $(26.67 \%)$, gill rot $(7.1 \%)$ and heamorrhagic lesion over the body surface (Figs. 3 and 4). Farmers also reported some occasional problems including round swollen haemorrhagic lesion in the muscle which later get bigger and changed into deep ulcerative lesion. Very often it caused serious mortality. In case of tilapia, pop eye (53.3\%), sudden floating in water surface with open mouth $(26.67 \%)$ and heamorrhage $(20.0 \%)$ were the major clinical signs of diseased fish (Figs. 6, 7and 8). In addition to this some other sings included reddening and deep lesion over body surface, fin rot, gill rot and in some case anal protrusion was also evident. Occasional Argulus infestations problem in tilapia was also reported by some farmers (Figs. 5 and 6).

\section{Seasonality of disease occurrence}

It was observed that $37.9 \%$ farmers faced disease problem in winter and in late winter while only $13.0 \%$ faced such problem in early winter. Some farms also noticed disease after heavy rainfall $(6.9 \%)$ and during summer (3.4\%) (Fig. 7).

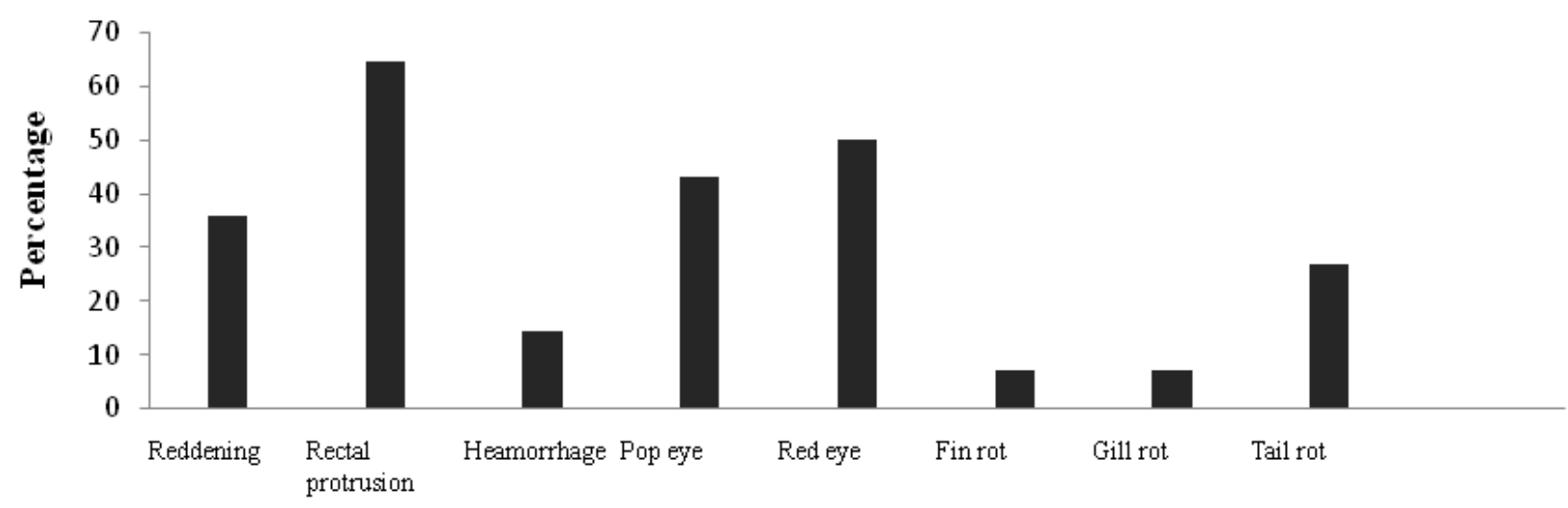

Clinical signs

Fig. 3.Major clinical signs (\%) of diseased pangus
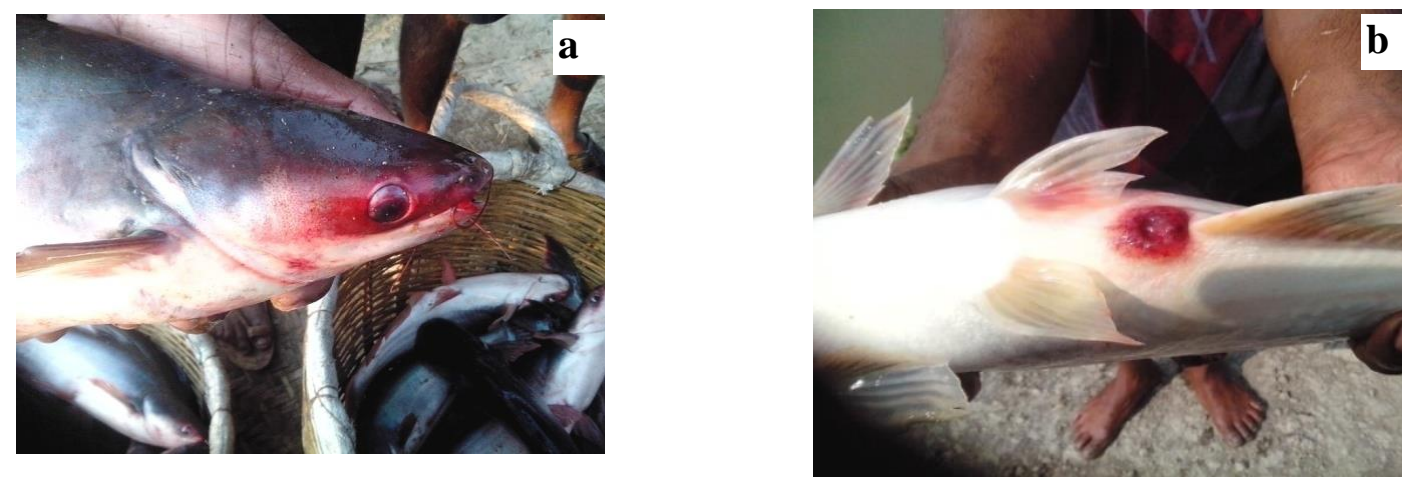

Fig. 4. Clinical signs of diseased pangus. (a) Mouth reddening and pop eye; (b) Anal protrusion 


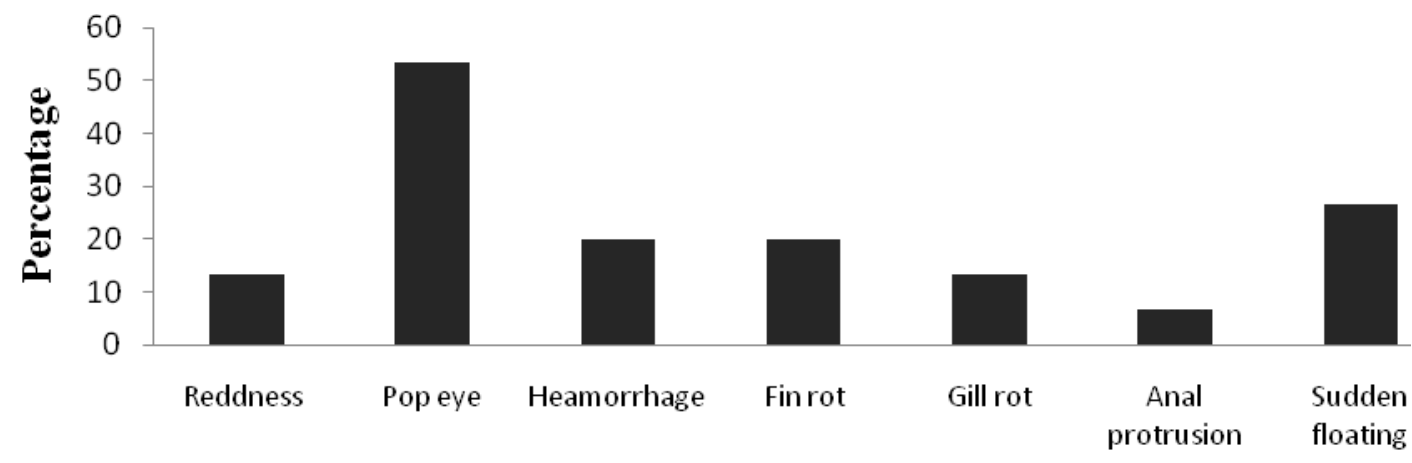

\section{Clinical signs}

Fig. 5.Major clinical signs (\%) of diseased tilapia.
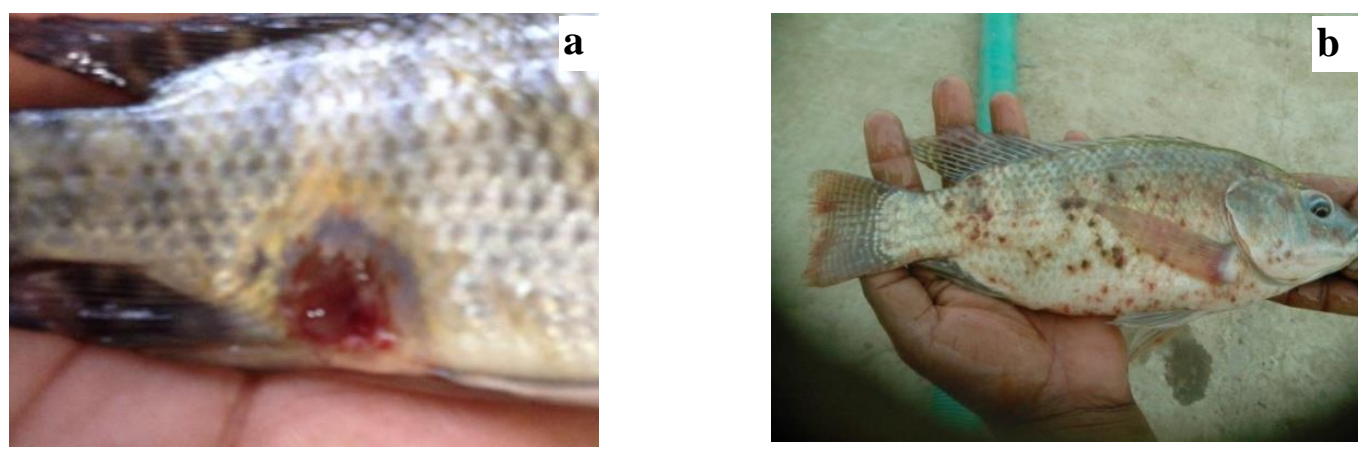

Fig. 6. Clinical sings of diseased tilapia. (a) Deep red lesion (b) Red spot due to Argulus infestation

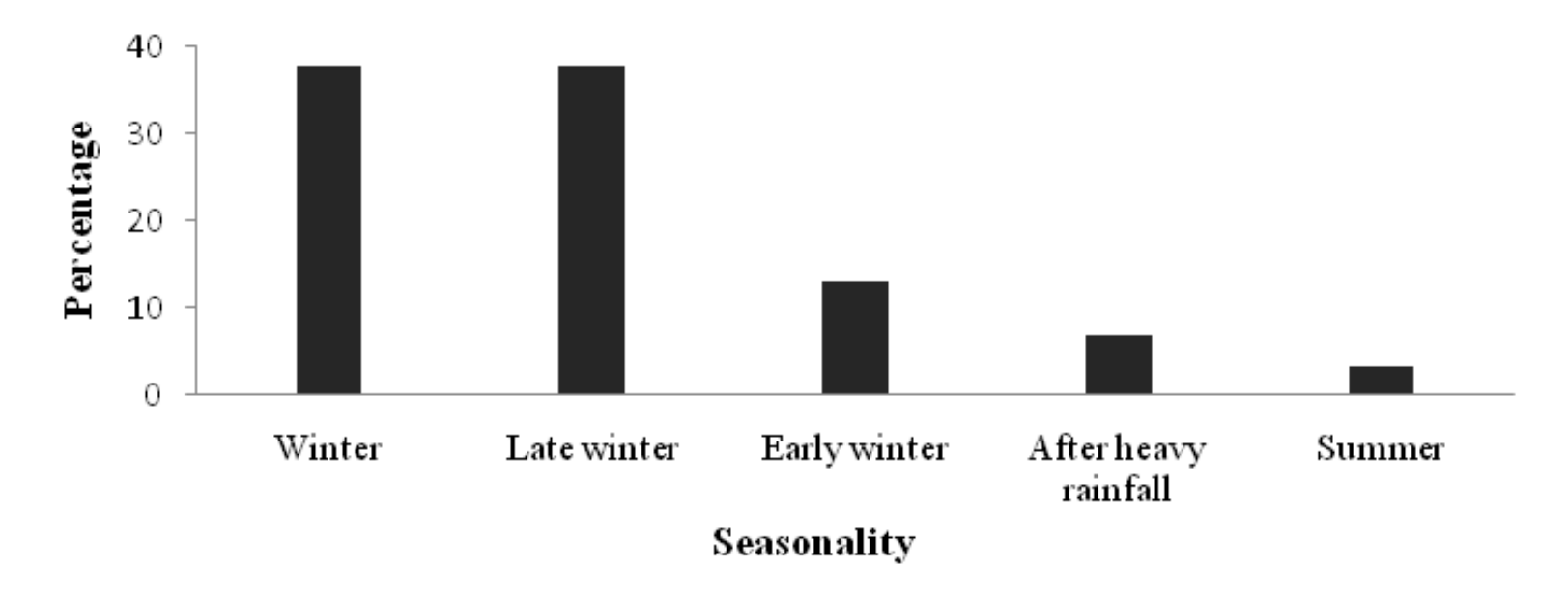

Fig. 7. Seasonality of disease occurrence

\section{Risk factors}

Farming of tilapia and pangus in polyculture system was commonly practiced by the farmers. Same ponds were used for both species and the possible disease causing risk factors were quite common. Risk factors of tilapia and pangus farming were addressed here through analyzing the following aspects of farming. In addition to quantitative data that was gathered through questionnaire interview, emphasis was also given on qualitative data collected through FGD with farmer.

Connection between farms: In the study area it was observed that that around $46.7 \%$ of tilapia farms were surrounded by many farms within $1 \mathrm{~km}$ area and $85.7 \%$ of pangus farms were in same condition. Farmers shared water within farms when needed. Only few farmers $(10.3 \%)$ shared water within their ponds through pipes. 
Due to breakage of dike some ponds were automatically connected with one another. Waterborne contamination with potentially harmful organisms might be possible in these farms.

Boundary of farm: In the present study, it was observed that only few farms were surrounded by boundaries while most of the farms did not have any boundary.

Connection of ponds to outside environment: Sometimes farmers used water from river and beel when needed. About $14.3 \%$ of tilapia farms directly connected to water bodies that may allow the entry of wild fish while about $35.7 \%$ pangus farms were found having scope to enter wild fish into the ponds.
Pre-stocking pond management: Questions were asked to the farmers regarding different aspects of pond preparation before releasing fish into the ponds. Little pond management including liming, use of high embankment of ponds (average 89.5\%) and others measures were undertaken by the farmers. Removal of bottom mud (54.8\%), draining of water $(71.9 \%)$, drying of pond $(58.1 \%)$, entry of wild fishes $(25.0 \%)$ and fencing around ponds were not as expected level in the farming area (Fig. 8). Some farmers prepared pond by using cow dung and fertilizer $(6.67 \%)$.

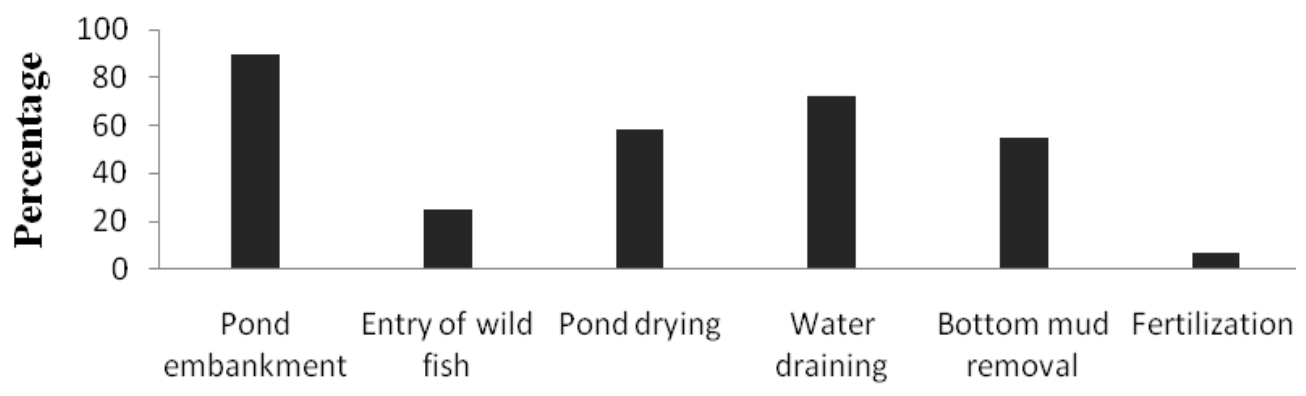

\section{Pond management related risks}

Fig. 8. Pond management related risks

Over-stocking: Appropriate stocking density of fish was not followed by the farmers. Most of the farmers stocked pangus in a stocking density 50,000-60,000 fry/ha and 40,000-50,000 fry/ha in case of tilapia. These stocking densities were much higher than recommended density. For polyculture farmers stocked $75 \%$ main species and $25 \%$ carps.

Improper feeding: It was observed that majority of the farmers did not feed their fish according to actual requirement. They used about two times more feed than requirement. Most of the pangus farms used home-made feed with mixture of rice bran, rice polish, flour, salt, soybean oil cake, meat and bone meal and many other ingredients.

Presence of predatory birds and livestock: Chil or Kite bird, pankouri or little black cormorant, herons, kingfisher, snake and water fowls were commonly found around farms. These birds could act as carriers of disease to other farms. Farmers tried to control predatory birds by hanging polythene rope over the ponds. Many farmers covered their pond with thin string to protect fish from birds (Fig. 9).
Grazing of cattle inside the farm were a most common phenomena (Fig. 9). About 55.2\% farmers had livestock (cow, goat and duck) which found grazing very often in their farms. These animals may also act as vector for disease.

Lack of farm hygiene: Farmershad no concern about hygiene of farm. No farm was found using any foot bath before entering into their farms and no farm workers were found using either any protective cloth, gum boot or hand wash. Majority farmer never washed their fish farming tools except sun drying. Vehicles (manual van, pick up van and truck) used for fish transportation were not washed regularly in proper way.

Sharing of farming equipment: Farming equipment should be kept separated between farms to avoid horizontal spreading of parasites or pathogens. But in the study area average $96.6 \%$ farmers shared their fish farming tools like nets, hapas, buckets and plastic bowls. 

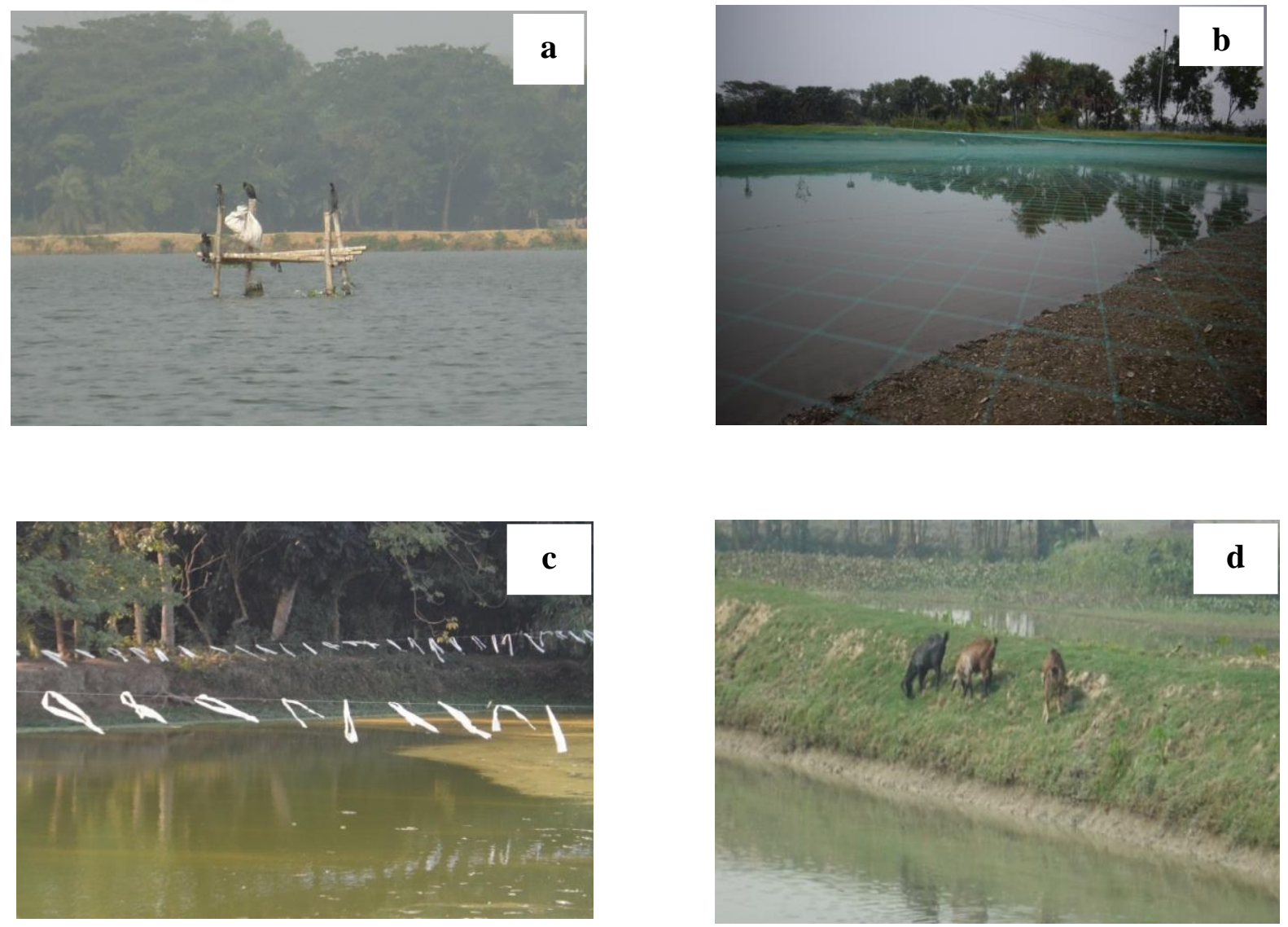

Fig. 9. Presence of predatory birds and livestock. (a) Presence of pankouri bird (Little black cormorant, Phalacrocorax sulcirostris) in a pangas farm, (b) Whole pond covered with nylon net, (c) Polythene tied with horizontal rope over the pond; (d) Cattle grazing inside the farm.

\section{Discussion}

Like other farming systems, aquaculture is plagued with disease problems resulting from its intensification and commercialization. The present study focused on the possible risk factors causing diseases in farmed tilapia and pangs. Among the recorded clinical signs anal protrusion and red spot on body surface were more prevalent in pangus while pop and red eye, gas problems were common in both pangus and tilapia. It was observed that disease problem was comparatively low in tilapia farms than pangus. Faruk (2012) reported red spot, anal protrusion, tail and fin rot, pop eye, dropsy and gill rot of farmed pangus of Bangladesh. The author also observed other conditions like cotton wool type lesion, ulceration and white spot with lower incidence. Anka (2013) found that, the most prevalent disease was anal protrusion and reddening around mouth and eyes.

Transmission of disease between farms is a possible risk factor. It was observed from the present study that distance between farms was not very much in the area. There were many farms located near one farm. The major risk could be associated with contact with other aquaculture sites. The bio-security status of the farm in term of farm hygiene and cleanliness were not up to standard. Almost all of the farmers in the study area shared their fish farming tools and they never clean the tools or equipment regularly. It may be a possible cause of disease contamination within farms. Risk analysis can integrate epidemiological data with other information including pathogen characteristics, the volume of movements of live aquatic animals and other movements (e.g. people and vehicles) on and off the farm, (Peeler, 2005).

Various aquatic birds were seen around pangus farms in the present study. They also posed risk of disease as carrier to the fishes of different ponds or from one farm to another. Birds also act as mechanical carriers of viruses and predator damage on fish can make the fishes 
susceptible to a number of diseases. Birds cause serious problem in juvenile fishes both tilapia and pangus. Farmers protect their fish by covering it with nets. According to Pillay (1992), a pelican can consume between 1 and 3 tonnes of fish per year and herons may cause losses up to $30-40 \%$ of fry and juvenile fish per year. Ross (1988) noted the methods of using predator netting in Scottish cage farms. In the study area many farmer cover their ponds with net.

In the present study, most of the pangus farms used home-made feed. Home-made feeds consist of many ingredients such as fish meal, soybean meal, corn, dried fish, meat bone meal, and poultry; therefore, it is difficult to keep records of all ingredients. In addition, home-made feeds are usually result in over-feeding, which causes pollution from residues. Waste (uneaten feed) is much higher if home-made feeds are used, which negatively affects pond water quality.

Pond drying was not a common practice since they practiced all year round fish production. Within 2-3 years they usually dry their ponds. Farmers were not interested to remove bottom mud after harvesting as they believe it is nutrient rich. Draining of water was not always done as farmers think nutrient rich water will bed rained.

Fish disease was commonly occurred in winter and late winter season. After heavy rainfall disease problems occur in some ponds. Sometimes disease was seen in summer season also. FAO (1989) reported that outbreak of disease was very commonly reported after rainfall, leading to suspicious that the runoff agricultural may have been important in predisposing cause for fish disease. Farmers could be suggested to take some preventive measures at the beginning of the winter season which include, application of lime and salt, disinfecting of equipment, addition of water, etc. (Faruk et al. 2004b).

In conclusion, pangus and tilapia are the two important culture species of Bangladesh for their fast growth, year round production and high productivity. Disease in fish culture causes huge loss in the industry. Present study highlighted some risk factors associated with the disease of these two species. It also identified some commonly occurring clinical signs of diseases. It is important to minimize disease causing factors and follow appropriate health management measures. All the diseases mentioned here could not be identified through laboratory analysis. Further research work should include more in-depth study on risk factor based epidemiology and identification and characterization of pathogens.

\section{References}

Anka, I.Z. 2013. Health and Environmental Issues of Emerging Pangas (Pangasianodon hypophthalmus) Farming. MS Thesis, Department of Aquaculture, BAU, Mymensingh.

Chowdhury M.B.R. 1998. Involvement of Aeromonad and Pseudomonads in Diseases of Farmed Fish in Bangladesh. Fish Pathol.,33:247-254.

FAO. 1989.Food and Agriculture Organization of the United Nations, Rome, Italy.

FAO. 2015.Food and Agriculture Organization of the United Nations, Annual Report 2013-2014, Rome, Italy.

Faruk, M.A.R., Sarker, M.M.R., Alam, M.J., Kabr, M.B. 2004. Economic Loss from Fish Diseases on Rural Freshwater Aquaculture of Bangladesh. PakistanJ.Bio.Sci., 7(12): 2086-2091.

Faruk, M.A.R., Alam, M.J., Sarker, M.M.R., Kabr, M.B. 2004b. Status of Fish Disease and Health Management Practices in Rural Freshwater Aquaculture of Bangladesh.PakistanJ.Bio.Sci., 7(12): 2092-2098.

Faruk, M.A.R., Patwary, Z.P., Hasan, M.M. 2012. Clinical and Histopathological Investigations in Exotic Catfish Pangasianodon hypophthalmus, (Sauvage, 1878) Under Culture Condition. Indian J. Fish., 59(4): 183-185.

Georgiadis, M.P, Gardner, I.A., Hedrick. R.P. 2001.The role of epidemiology in the prevention, diagnosis, and control of infectious diseases in fish.Prev. Vet. Med., 48:287-302

Haque, M.M., Monir, M. S., Salam, M. A., Shinn, A.P. Little, D. C. 2013. Use of pangasius pond sediment for rooftop bag gardening: potential for rural-urban integrated aquaculturehorticulture. Aquaculture Asia, Volume XVIII (4): 21-23 October-December, 2013

Hedrick, R.P. 1998. Relationships of the host, pathogen and environment: implications for diseases of cultured and wild fish populations. J. Aquat. Anim. Health, 10:107-111.

Kumer, J.S.S. 2006. Practical Guide for the Management of Intensive Catfish Farming. Animal Care Services Publication Ltd. Oghere, Ogun State, Nigeria 3.

Peeler, E. 2005. The Role of Risk Analysis and Epidemiology in the Development of Biosecurity for Aquaculture. Fish Health Section, Asian Fisheries Society, Manila. Diseases in Asian Aquaculture V 35-45.

Pillay, T.V.R. 1992. Aquaculture and the Environment. Fishing News Books, Cambridge, USA 6-95.

Ross, A. 1988. Controlling Natures Predators on Fish Farms. Marine Conservation Society 96.

Thorburn, M.A. 1996.Apparent prevalence of fish pathogens in asymptomatic salmonid populations and its effect on misclassifying population infection status.J. Aquat. Anim. Health., 8:271-277

WHO, 2016. World Health Organization, Health Topics, Penang Malaysia. 